DIGITAL COMMONS
@ UNIVERSITY OF SOUTH FLORIDA

Volume 2

Issue 2 Volume 2.2 (Fall 2012): Open Access

\section{ABO: Interactive Journal for Women in the Arts, 1640-1830}

2012

\title{
A Deeply-Felt (and Somewhat Revised) Rant: Women, Children and Funding in the Ivory Tower
}

Nora Nachumi

Yeshiva University, nachumi@yu.edu

Follow this and additional works at: https://digitalcommons.usf.edu/abo

Part of the Dramatic Literature, Criticism and Theory Commons, Educational Methods Commons, Feminist, Gender, and Sexuality Studies Commons, and the Literature in English, British Isles Commons

\section{Recommended Citation}

Nachumi, Nora (2012) "A Deeply-Felt (and Somewhat Revised) Rant: Women, Children and Funding in the Ivory Tower," ABO: Interactive Journal for Women in the Arts, 1640-1830: Vol.2: Iss.2, Article 6. http://dx.doi.org/10.5038/2157-7129.2.2.6

Available at: https://digitalcommons.usf.edu/abo/vol2/iss2/6

This Scholarship is brought to you for free and open access by Digital Commons @ University of South Florida. It has been accepted for inclusion in ABO: Interactive Journal for Women in the Arts, 1640-1830 by an authorized administrator of Digital Commons @ University of South Florida. For more information, please contact digitalcommons@usf.edu. 


\section{A Deeply-Felt (and Somewhat Revised) Rant: Women, Children and Funding in the Ivory Tower}

\section{Keywords}

children, fellowship, funding, promotion, publication, research, state of the profession, tenure

Creative Commons License

(c) $($ ) $\Theta$

This work is licensed under a Creative Commons Attribution-No Derivative Works 3.0 License. 
What follows is considerably more precise and well-documented than what I said when I spoke on last year's roundtable. You see, as I sat there, listening to incredibly helpful advice from junior and senior scholars alike, I felt overwhelmed with frustration. My plan-which was to talk about talk about funding women's studies programs—-went out the window. "The problem," I said, when I opened my mouth, "is that our profession in general, and funding opportunities in particular, are not set up to accommodate parents and-dare I say it?-especially mothers with small children at home." And then I complained.

My point, of course, was neither new nor original. A slew of articles have been written documenting gender-based inequities among academics. The figures are telling. Although more women than men go to college, fewer women than men earn Ph.D.s. More men than women are hired for tenure-track positions and the gap widens as careers stall or advance. Children, researchers point out, make a huge difference to the careers of women in academia. Women who have babies early - approximately five years or less after earning the Ph.D. are less likely to earn tenure than both their male colleagues and childless women. "While many thirty-somethingsincluding those with master's degrees and professional jobs-spend evenings and weekends piling into minivans for play dates and trips to the park, post docs are expected to supply their tenure committees with research, get published, teach undergrads and advise graduate students expertly and often," remarks Gregory Patterson. Meanwhile, those who have babies after tenure also lag behind their male and childless counterparts. "Overall," Mary Ann Mason and Marc Goulden point out,

women who attain tenure across the disciplines are unlikely to have children in the household. Twelve to fourteen years out from the Ph.D., 62 percent of tenured women in the humanities and social sciences and 50 percent of those in the sciences do not have children in the household. By contrast, only 39 percent of tenured men in social sciences and humanities and 30 percent of those in the sciences do not have children in the household 12 to 14 years out from the Ph.D. (Mason)

Despite advances made by women in higher education, having children thus remains a different proposition for male academics than it is for their female colleagues. To be fair, it is not the only factor influencing the disparity. Women with Ph.D.s are far more likely than their male counterparts to marry partners with advanced degrees, for example, and to face dilemmas stemming from duel career constraints (Wolfinger 401).

But to return to my point: the cost of doing research—both financial and otherwise-is higher for female academics once they have children. Let's say, for example, that an American scholar with a young child needs to visit a library in another state. What are her options? With luck, she can afford on her own to pay for her room and board and spend a week doing research. However, if her children are young, how long can she leave them? One ticket thus may require two or more additional tickets with a concomitant increase in the cost for room, board and childcaredepending on whether or not the scholar's partner (if she has one) can come along for the trip. Needless to say, all this becomes more expensive and complicated if the research requires travel abroad or multiple trips to different locations. 
Fellowships are supposed to help with the expenses research, but they too can be problematic. Those attached to universities and to research libraries often have residency requirements. A short-term residential fellowship at the Folger, Newberry, or Walpole, for example, requires the holder spend at least one continuous month on site. Fellowships for longer terms generally require residency for four months to a year. Fellowships that aren't attached to locations generally have stipulations regarding the kinds of expenses they will support. A Guggenheim is one of only a few fellowships I know of that leaves scholars free to spend funds as they see fit. So, if I win a Guggenheim (for which I would gladly sacrifice any number of chickens) I can pay for a babysitter out of the funds. That is, of course, if I' $m$ on sabbatical. Otherwise, I have to return part of my salary to my institution to pay someone else to teach my courses. Then the funds from the Guggenheim (or whatever I win in my fantasy fellowship league) would not be sufficient for extra child care beyond what I already pay in order to teach.

Of course some of us are lucky enough to be in two-income families and our partners make enough money to make up the difference. But some of us don't have that luxury. Those of us who do have partners who make significant salaries usually also have partners who work extremely long hours. Regardless, unless a scholar is part of an academic couple odds are she/he has the more flexible schedule and so does the majority of childcare during the week.

Thus another issue arises: even if scholars with children had the funding to work at research libraries for months at a time, could they take that time away from their family responsibilities? Perhaps when one has college-aged children but for those of us whose children still need their parent(s) on a daily basis, leaving them for weeks at a time would require making choices that adversely affect the entire family. And what if one's child has special needs? Mine does and I'm not the only mother I know who has had to take a year off from writing and research in order to ensure her child has the medical, educational and therapeutic supports he or she needs in order to survive. But that's a whole other essay. My point here is that change needs to happen in order for women with children to secure funding for research and writing. We need residential fellowships that allow us to break up our time into small segments and more large fellowships that allow us to use funds to pay for child care. We need more policies like that at the University of Michigan, which gives "tenure-track faculty with new children one semester out of the classroom with full pay and one year's cessation of the tenure clock" (Patterson). In addition to childbirth leave and time off the tenure clock, the University of California at Berkeley provides "a breastfeeding support program, two large complexes of student-family housing and a graduate student parent grant of up to $\$ 8,000 "$ (Patterson). Also on the hit parade is The Georgia Institute of Technology, "the school that awards more doctoral degrees in engineering than any other" which used "part of a five-year grant from the National Science Foundation to promote the advancement of women in the sciences to pay for time out of the class for postdoctoral faculty who became new parents - and to pay for a lactation room" (Patterson). We need affordable, convenient child care on campus.

What we are paid also needs to change. Currently women earn "roughly 75 to 77 percent of what their male counterparts earn in academia" (Allen 117). Institutions need to remedy gender-based salary inequities - not only because not doing so is immoral, but because we need money to travel to libraries or to stay home and write. 
Our ideas about what constitutes reasonable output for promotion and tenure needs to be more flexible. Research consistently supports the position that "the dual role assumed by some women (career academics and mother/wife) significantly impacts the time and energy women may have available to dedicate to preparing and submitting journal articles which are widely recognized within academia as labour intensive research endeavors" (Hartley pg). With evidence like this in mind, the "University and College Union has urged the UK funding councils to allow female academics to submit one fewer output to the research excellence framework for each pregnancy they have during the census period" (Jump 14). Perhaps we need to rethink the "one book (or seven refereed articles) fits all" model. Quantity and quality are not synonyms after all.

Women need to keep mentoring each other. The support of senior colleagues who are managing to balance the demands of their families and their careers is immensely important to the next generation of female academics with children (Gardiner et. al. 438-40). We also would benefit from encouraging greater solidarity among women, with or without children, at all stages of their careers. Current scholarship reveals that most "formalized programs are designed for those in the early stages of their careers" (Allan 109). However, evidence suggests that mentoring may be "equally important for women who are later in their careers. For instance, post-tenure mentoring may help to rectify the problem of 'stalled out' careers for women who plateau at the associate professor level" (Allan 109). Since many women who "stall out" do so due to the difficulty of balancing the demands of family and career, mentoring by women who have passed this point in their own careers could help immensely.

Considered together, these recommendations call attention to the need for a more profound change in the way the academy — and we academics — regard female scholars with children. Currently the question of how to support female researchers with children seeks to compensate for the cost of raising children. Instead, we need to be asking how supporting female scholars with children might benefit the academy. Perhaps it might make some of us better teachers and scholars. At the very least, we would stop losing talented women by asking them to prioritize either their families or their careers.

\section{Works Cited}

Allan, Elizabeth J. “Advancing Women's Status: Analyzing Predominant Change Strategies." ASHE Higher Education Report 2011.37.1 (2011): 93-118. Web. 30 August 2012.

Gardiner, Maria, MarikaTiggermann, Hugh Kearnes and Kelly Marshall. "Show Me the Money! An empirical analysis of mentoring outcomes for women in academia." Higher Education Research and Development 26: 4 (December 2007): 425-42. Web. 20 August, 2012.

Hartley, Nicole and Angela Dobele. "Feathers in the Nest: Establishing a Supportive Environment for Women Researchers." The Austrialian Educational Researcher 36.1 (April 2009): 43-58. Web. 20 August 2012.

Jump, Paul. “(Re)productive Reasoning on Personal Output.” Times Literary Supplement 6 October 2011: 14. Web. 29 August 2012. 
Mason, Mary Ann and Paul Gould. "Do Babies Matter?: The Effect of Family Formation on the Lifelong Careers of Academic Men and Women." Academe Online. November 2002. Web. 20 August 2012.

Patterson, Gregory A. "Managing Motherhood and Tenure." Diverse: Issues in Higher Education. 25.2013 November 2008. Web. 29 August 2012.

Wolfinger, Nicholas H., Mary Ann Mason, Marc Goulden. "Problems in the Pipeline: Gender, Marriage, and Fertility in the Ivory Tower. The Journal of Higher Education.79.4 (July/August 2008): 389-405. Web. 20 August, 2012. 